\title{
The Increase in Child-Friendly Learning Management towards the Formation of Students' Character in Inclusive Elementary School
}

\author{
Moh Toharudin ${ }^{1}$, Totok Sumaryanto Florentinus ${ }^{2}$, Rasdi Ekosiswoyo ${ }^{3}$, Joko Sutarto ${ }^{4}$ \\ ${ }_{1,2,3,4}$ Graduate School, Universitas Negeri Semarang, Indonesia \\ ${ }^{1}$ Corresponding email: sunantoha12@gmail.com
}

\begin{abstract}
The purpose of this study was to describe and analyze a child-friendly learning planning, the implementation of a child-friendly learning, and child-friendly learning evaluation. Meanwhile, the research method used was qualitative interpretive. This method was used to analyse and interpret the management of child-friendly learning at four elementary schools inclusive in Brebes with the subjects of this research were as many as 24 classroom teachers. For more, the data collection techniques used were interviews, observation and documentation. The results of this study were the planning of learning set a goal of learning tailored to the needs of children, the development of a syllabus and lesson plan which was modified to the child's condition, classroom planning management, strategy approach to learning activities based on students, and learning activities of the child-friendly procedures; the learning was aimed to give motivation to students, learn to use media to suit the needs of students, apply learning methods that involve students, provide concrete examples known to students. Meanwhile, the character values given to students were in the form of fair treatment, application of norms of religion, social norms and local culture, affection, and respect each other; the evaluation of the learning was done by means of flexible assessment, while the assessment was adjusted to the conditions of the various needs of learners.
\end{abstract}

Keywords: Child-Friendly, Learning Management

\section{Introduction}

Inclusive education is a government solution in providing learning services that include children in need of special children study together with their age in the regular school nearest to the place of residence. Conducting inclusive education demands the school to make adjustments both in terms of curricula, educational facilities and infrastructure, as well as a system of learning adjusted to the individual needs of learners (the directorate of PSLB, 2004).

Elementary school performs a place to instill and develop students' character values (manners) through conditioning performed by the teacher the school surroundings. Conditioning is done to make the school environment can be a conducive place to seed and develop the character of optimism, develop reasoning, enlighten minds, provide skills and attitudes required to make students have honesty, manners, creativity, productivity, selfsufficiency, and be beneficial to each other. A kind of learning that allows students to have character values is materialized through childfriendly learning management. Teachers as a learning community place student at the center of learning, encourage students' participation in learning, understand and utilize adaptive learning media, and also have an interest to provide best service for students.

The problem of learning activities found in elementary schools in Brebes covered various obstacles, including a low level of teacher's competence related to curriculum modification and learning management. This is in line with the result of the study of Valeo from Ryeson University (2008) who researched the system of support in implementing inclusive education. They found that there is a difference in perception between teachers and administrators in implementing inclusive education. The teachers felt frustrated because the demands of the curriculum and time limitations. Also, the cooperation between classroom teachers and special counselors are still not optimal.

Based on the background, the researchers intended to find out how child-friendly learning management is applied by teacher class in primary school in order to develop the inclusive character of the students in Brebes. The results of this research were expected to benefit both 
theoretically, gave an overview of information related to the way teachers can craft learning devices, learn and execute the compiled assessment and learning instruments so that children can develop the inclusive character at the elementary school.

\section{Methods}

This study used qualitative interpretive approach. According to Creswell (2014), a qualitative research method is used to explore and understand the meaning by involving a number of individuals or a group of people derived from social or humanitarian problems.

Furthermore, the setting of this study was in Elementary School (SD) Brebes 03, SD Klampok 01, SD Tanjung 01 and SD Kalierang 03 . The investigation was carried out in January until June 2017. It started with initial observation, preparation, study of literature, the preparation of guidelines for interview, observation guidelines, data collection in the field, data analysis and data reporting. The data collected in this study must be appropriate in line with focus and study purposes. Moreover, the data were obtained from the ongoing behavior of the subjects of the study related to child-friendly learning in shaping the character of students.

The data sources in this study were taken from the teachers of class 1 until class 6 amounted to 24 people. Meanwhile, the data collection were done by using interviews, observation, and documentation. In order to make this study data valid, there was a need to conduct data validity using triangulation (checking data from different sources in different ways). There were three triangulation applied in this study, namely data triangulation, data source, and triangulation methods of data collection.

\section{Results and Discussion}

Child-friendly learning management in inclusive elementary schools were intended as a learning management system starting from the planning, implementation and evaluation. All students involved in this management were selected without discriminating gender, religion, strata or social background. For more, in Brebes, there are four elementary schools which host child-friendly learning,. They are SD Brebes 03 which accepts students from various types of needs of both regular students or students in need for the community of east Brebes, SD Klampok 01 which accepts students from various types of needs for the community of centre Brebes, SD Tanjung 01 which accepts students of various kinds needs to community west of Brebes, and SD Kalierang 03 which accepts students from various types of needs for the community of south Brebes.

Learning activities on the four inclusive elementary schools were designed in accordance with the needs, the ability and the characteristics of the students as well as by referring to the curriculum modification to the needs of students. Additionally, child-friendly learning management in shaping the character of the students at the elementary school inclusive was done by teacher with three stages, namely the planning, implementation, and the evaluation of the child-friendly learning.

Child-friendly learning planning in shaping the character of the inclusive elementary school students was conducted by the teachers, covering setting learning objectives based on each learner's needs, developing syllabus and lesson plan (RPP) modified to the condition of students with different types of needs, planning a classroom management, establishing and organizing materials to teach, planning strategy approach learning activities based on students' need, planning learning activities of child friendly procedures, planning the use of resources and learning media in accordance with the conditions of the students, and creating assessment for students after the plans were completed, as well as the form of desirable follow up.

Planning a child-friendly learning in inclusive elementary schools was done by the inclusive educational working groups appointed by the education authorities in Brebes, created description of each learning objectives based on the needs of each students and developed assessment to measure the success of the learning of all students. Elementary school learning inclusive planning was carried out by means of harmonizing standards of competence in the national curriculum with the condition of each student in need. This is in line with the explanation of The Ministry of National Education Regulation (Permendiknas) number 
70 year 2009 that units of education for inclusive education providers use a curriculum unit of education that accommodates the needs and abilities of students in accordance with the talent, and their interest.

Learning is a process planning decision making based on the results of rational thoughts, goals and learning objectives, changes in the behaviour of students as well as the efforts that must be made by teachers to achieve objectives of the learning. The following table presents child-friendly learning planning differences on inclusive elementary schools with regular school which are commonly implemented in Brebes.

Table 1. Child-friendly learning planning.

\begin{tabular}{lll}
\hline No & \multicolumn{1}{c}{ Inclusive Elementary School } & \multicolumn{1}{c}{ Regular Elementary School } \\
\hline 1. & $\begin{array}{l}\text { modification of the lesson plan and the syllabus } \\
\text { of instruction to the needs of students } \\
\text { Activity sheet for students are targeted in } \\
\text { accordance with the individual's ability of } \\
\text { students in need of special }\end{array}$ & $\begin{array}{l}\text { lesson plan and the syllabus of learning following the } \\
\text { instructions of education authorities. } \\
\text { Activity sheets for students are targeted in accordance } \\
\text { with the standards of the standar value at school }\end{array}$ \\
3. $\quad \begin{array}{l}\text { Media and learning resources are modified for } \\
\text { each student's needs. }\end{array}$ & $\begin{array}{l}\text { Media and learning resources are modified for the } \\
\text { subject matter }\end{array}$ \\
4. $\begin{array}{l}\text { Learning scenarios are done by applying } \\
\text { individual learning program. }\end{array}$ & $\begin{array}{l}\text { Learning scenarios are done by applying learning } \\
\text { groups. } \\
\text { 5. } \quad \begin{array}{l}\text { Learning assessment instruments are modified to } \\
\text { the specific conditions of the students in need. }\end{array}\end{array}$ & $\begin{array}{l}\text { learning objectives in general. } \\
\text { List of present students in general }\end{array}$ \\
6. $\begin{array}{l}\text { List of values are based on the conditions of } \\
\text { individual students }\end{array}$ & $\begin{array}{l}\text { Customized learning journals for students } \\
\text { between meeting and learning curriculum. }\end{array}$ & $\begin{array}{l}\text { Customized learning journal based on learning } \\
\text { curriculum. }\end{array}$ \\
\hline
\end{tabular}

The implementation of a child-friendly learning was done in shaping the character of teacher students in inclusive elementary schools in Brebes, namely manner: fair treatment to all students, the application of religious norms, application of social norms and culture local, compassion to all the students, mutual respect for the rights of the child both between students andteachers. Meanwhile, the implementation of learning which was implemented by the teachers in the classroom was done by having teacher gave the motivation of learning to all students without discrimination, teachers used learning media in accordance with the themes that they taught, teachers applied learning method which involved students, teachers provided concrete examples that were recognized by students such as safeguarding environment, and asked questions that relate to the materials submitted earlie, as well as evaluating the students' ability through the granting of questions directly or providing a task reserved to do at home.

The implementation of learning activities in inclusive elementary school in general was equal to the implementation of learning activities in a regular elementary school. It happened so because in inclusive elementary school, there are very heterogeneous learners, then the lesson activities are aimed at applying not only the principles of learning in general, but also applying special learning principles in accordance with the needs of the students. Child-friendly teaching and learning activities in inclusive elementary school will be different both in learning strategies, learning procedures, methods, and instructional media. At the elementary school teachers should be inclusive to accommodate all the needs of students including understanding to provide each learner differences.

The learning activities of inclusive elementary school were implemented through several stages, namely interaction with all students, teachers always respond to students' questions, and provide an explanation as well as an understanding of the materials to all students both regular students or students in need of special and apply learning interaction which can give rise to all students; apply the method of learning based on the needs of students, at this stage the inclusive elementary school teachers apply various learning methods at the same time; 
for example, at the beginning of a learning, the method used is lecturing, a discussion and awarding of the task. As for the next learning methods the teachers may do individual learning for students in need.

Implementation of learning is the implementation of the study plan, including the preliminary activities, core and cover. In preliminary activities, teachers prepare students psychologically and physically to follow learning process, give students learning motivation which give contextually appropriate benefits and give applications of learning materials in everyday life by giving examples and comparisons for local, national and international; ask questions that relate prior knowledge with the material to be studied; explain the basic competencies or learning objectives that will be achieved; and convey the scope of the description and explanation of material activities appropriate syllabus. The core activities are done by using a model of learning, learning methods, media of learning, and learning resources tailored to the characteristics of the students and subject. This opinion is in line with Arismantoro's (2008) that childfriendly education is creating a conducive learning environment so that children can learn effectively in the atmosphere that gives a sense of security, without threats, and provide spirit. The implementation of learning forms the attitude of students in accordance with the characteristics of the attitude. To do so, teachers can do one of the chosen alternative, namely the process of affection ranging from a receiving, running, cherish, appreciation, to practice. The whole activities of learning-oriented competence stages encourage students to perform such activities. In the closing activity, students share reflections evaluate with the teachers both individually and in group. The following is presented the differences of implementation of child friendly learning at the inclusive elementary school and regular schools.

Table 2. The Implementation of child-friendly learning in inclusive elementary school

\begin{tabular}{|c|c|c|}
\hline No & Iinclusive Elementary School & Regular Elementary School \\
\hline 1 & $\begin{array}{l}\text { Teacher always provide the motivation of learning to all } \\
\text { students }\end{array}$ & $\begin{array}{l}\text { Teacher sometimes give the motivation of learning to } \\
\text { the students. }\end{array}$ \\
\hline 2 & $\begin{array}{l}\text { Teachers know and understand the whole character of } \\
\text { the students }\end{array}$ & $\begin{array}{l}\text { Teachers know and understand some of the character } \\
\text { of the students }\end{array}$ \\
\hline 3 & $\begin{array}{l}\text { Teachers always formulate learning objectives clearly, } \\
\text { prepare materials, and media that suit the students }\end{array}$ & $\begin{array}{l}\text { Teachers do not formulate learning objectives clearly, } \\
\text { don't prepare learning materials, and the appropriate } \\
\text { media. }\end{array}$ \\
\hline 4 & $\begin{array}{l}\text { Teachers always develop learning strategies that are } \\
\text { able to optimize the interaction between teachers and } \\
\text { students, students and students, teachers with students } \\
\text { and the environment as well as the interaction from } \\
\text { many directions }\end{array}$ & $\begin{array}{l}\text { Teachers are less creative in developing learning } \\
\text { strategies that can optimize the interaction between } \\
\text { teachers and students, teachers with students and the } \\
\text { environment as well as the interaction from many } \\
\text { directions }\end{array}$ \\
\hline 5 & $\begin{array}{l}\text { Teachers always give the opportunity to the children to } \\
\text { engage in the practice, or formulate something through } \\
\text { observation, research or the like. }\end{array}$ & $\begin{array}{l}\text { Teachers do not give the opportunity to the children } \\
\text { to engage in the practice, or formulate something } \\
\text { through observation, research or the like. }\end{array}$ \\
\hline 6 & $\begin{array}{l}\text { Teachers know the initial capabilities and } \\
\text { characteristics of each student in depth, in terms of } \\
\text { traffic as well as its inability to absorb the material in } \\
\text { learning, his slowness or speed in learning, and } \\
\text { behavior, so that the learning activities of each student } \\
\text { get the attention and the appropriate treatment }\end{array}$ & $\begin{array}{l}\text { Teachers know the initial capabilities and } \\
\text { characteristics of each student in depth, in terms of } \\
\text { traffic as well as its inability to absorb the material in } \\
\text { learning, his speed or slowness in learning, and } \\
\text { behavior, so that learning activities of each student } \\
\text { get the attention and the appropriate treatment }\end{array}$ \\
\hline 7 & $\begin{array}{l}\text { Teachers develop learning strategies that are able to } \\
\text { lure students to engage actively, either physically, } \\
\text { mentally, socially, and emotionally. }\end{array}$ & $\begin{array}{l}\text { Teachers do not develop learning strategies that are } \\
\text { able to lure students to engage actively, either } \\
\text { physically, mentally, socially, and emotionally. }\end{array}$ \\
\hline 8 & $\begin{array}{l}\text { Teachers often ask various issues or problems that exist } \\
\text { in the environment, and the child is trained to } \\
\text { formulate, searching for data, analyze and solve it in } \\
\text { accordance with its ability. }\end{array}$ & $\begin{array}{l}\text { Teachers often ask various issues or problems that } \\
\text { exist in the environment, and the child is trained to } \\
\text { formulate, searching for data, analyze and solve it in } \\
\text { accordance with its ability. }\end{array}$ \\
\hline
\end{tabular}


Child-friendly learning evaluation in shaping the character of students conducted by inclusive elementary school teachers is by way of a flexible assessment, namely the assessments are tailored to the conditions of the various types of needs of students. This opinion is in line with Budimansyah's (2002) that a good assessment should pay attention to the conditions and individual differences. Meanwhile, the components evaluated are: (1) the cognitive evaluation, assessment to measure understanding of student learning. Knowledge is owned through the activity of knowing, understanding, applying, analyzing, evaluating, and created. The characteristics of the learning activities in the domain of knowledge have differences and similarities with the learning activities in the domain of skills. To encourage the students to produce creative works and contextual, either individual or group, it is recommended to use a learning approach that produces a paper based troubleshooting; (2) the evaluation of the affective to gauge the attitude of the students during instruction. According to the characteristics of the attitude, one of the chosen alternatives is the process of affection ranging from a receiving, running, cherish, appreciate, to practice. The whole activities of learning are oriented to competence stages that encourage students to perform those activities; and (3) evaluation of psychomotor skills students' practice for measuring the learning. Skills are acquired through activities to observe, ask your self, try, reasoning, convey, and create. The entire contents of the material (topics and subtopik) subjects derived from skills should encourage students to do the process of observation to the creation. To realize these skills, there is a need to do learning that applies model based learning/research disclosure (discovery/ inquiry learning) and learning that produces paper based problem solving (project based learning).

Evaluation of learning in inclusive education considers the principles of learning tailored to the characteristics of students with learning how to perform simultaneous and ongoing evaluation. This is the same as the results of the study by Syafrida, (2013) about the attitudes of teachers towards the inclusion of education in terms of attitude-forming factors on four primary inclusions in Surabaya. The result was the attitude of the teachers consists of a positive attitude that is received against a negative attitude of inclusion and education is refused education inclusion. Factors that appear are the background of teachers, views of child in need of a special type, teacher, grade level, teacher beliefs, views the socio political, empathetic teachers and gender. The second factor of the experience, consists of: teaching students in need of special and experience contact with the crew on board. These three factors, namely the knowledge level of teacher education, training, knowledge and learning needs of teachers. The four factors of environmental education, consisting of support resources, parent support, their families and the school system.

\section{Conclusions}

Child-friendly learning planning in shaping the character of students conducted by the teachers covers setting a goal of learning tailored to the needs of children, developing a syllabus and lesson plan modified to the condition of the child, classroom management planning, planning learning activities approach strategy centered on students, planning learning activities of child-friendly procedures, planning the use of resources and in accordance with the learning media the condition of the students, and planning the assessment of students after completing tasks in a process of learning, as well as the form of follow up which is desirable.

The implementation of a child-friendly learning done in shaping the character of teacher students in inclusive elementary schools in Brebes gives the motivation of learning to all students without discrimination, uses the appropriate learning media with the needs of students, applies learning methods that involve students.

Child-friendly learning evaluation in shaping the character of students conducted by inclusive elementary school teacher is by way of a flexible assessment, namely the assessments are tailored to the conditions of the various needs of students. While the components evaluated include the evaluation of cognitive, 
affective, and evaluation of psychomotor evaluation.

\section{References}

Arismantoro. 2008. Strategi Pembelajaran. Jakarta: Directorate General of Higher Education Department of National Education Department.

Creswell W. John. 2013. Research Design Pendekatan Kualitatif, Kuantitatif, dan Mixed. Yogyakarta: Pustaka Pelajar

Gonzalez-Gil, F. et al. 2013. Teaching, Learning and Inclusive Education: The Challenge of Teachers' Training for Inclusion. Procedi-Social and Behaviorial Sciences. 93 (2013) 783-788.

Sugiyono. 2007. Metode Penelitian Pendidikan, Pendekatan Kuantitatif, Kualitatif dan $R \& D$. Bandung: Penerbit Alfabeta.

The Amendment of 1945 Constitution of the Republic of Indonesia and its explanation: Surabaya: Serbajaya
The Directorate of Special School Education. (2004). Manajemen Sekolah dalam Pendidikan Inklusif. Jakarta.

The Ministry of National Education Regulation No. 70 year 2009 on Inclusive Education for Students with Disabilities and / or Students with Potential Intelligence and / or Special Talents. Available at: http://peduliinklusi.blogspot.com /2009/11/permendiknas-no-70-tahun-2009 tentang.html, accessed on $12^{\text {th }}$ of March 2017.

Valeo, A. 2008. Inclusive Education Supprot System: Teacher and Administrator Views. International Journal of Special Education. 23(2), 8-16.

Zamroni. 2011. Strategi dan Model Implementasi Pendidikan Karakter di Sekolah" dalam Darmiyati Zuchdi dkk. (ed.). Pendidikan Karakter dalam Perspektif Teori dan Praktik. Yogyakarta: UNY Press. 